\title{
TINJAUAN TEKNOLOGI INAKTIVASI VIRUS UNTUK PENANGGULANGAN PANDEMI COVID-19
}

\section{Review of Virus Inactivation Technologies for Covid-19 Pandemic Control}

\author{
Joko Prayitno*, Rahmania Admirasari, Joko P Susanto, Rudi Nugroho \\ Pusat Teknologi Lingkungan BPPT, Gedung 820 Geostek, Kawasan Puspiptek, Tangerang Selatan, Banten \\ *Email: joko.prayitno@bppt.go.id
}

\begin{abstract}
SARS-CoV-2 virus inactivation is one of global concerns in alleviating the spread of Covid-19. The applications of virus inactivation technologies are mainly based on the knowledge of virus characteristics, its persistence on material surfaces, and environmental factors impairing its structure. Current virus inactivation methods are mostly employing chemicals dan physical treatments such as hydrogen peroxide, hypochlorite solutions, and UV light. In this paper, we discuss three current virus inactivation technologies for reducing the spread of Covid-19, i.e., room disinfection, surface disinfection, and personal protective equipment (PPE) decontamination technology. Room disinfection technology, particularly room with poor ventilation or closed air circulation, employs the combination of UV light treatment with filters. Surface disinfection technologies utilize the spraying or fogging of disinfectant solutions, and PPE decontamination technologies utilize UV light or chemical treatments to inactivate the virus. Further development and application of these technologies will help the national effort in controlling the spread of Covid-19.
\end{abstract}

Keywords: Covid-19, disinfection, SARS-CoV-2, UV, virus inactivation

\begin{abstract}
ABSTRAK
Inaktivasi virus SARS-CoV-2 merupakan salah satu upaya global untuk mengurangi penyebaran Covid-19. Aplikasi teknologi inaktivasi virus ini banyak bersandar pada pengetahuan mengenai karakteristik dan daya tahan virus ini pada permukaan benda dan halhal yang merusak struktur virus tersebut. Metode inaktivasi virus yang banyak digunakan adalah perlakuan dengan bahan kimia dan perlakuan secara fisik yaitu dengan menggunakan larutan disinfektan hidrogen peroksida, larutan hipoklorit dan sinar UV. Dalam tulisan ini, peluang aplikasi teknologi inaktivasi virus SARS-CoV-2 yang dibahas adalah teknologi disinfeksi ruangan, disinfeksi permukaan benda dan dekontaminasi alat pelindung diri. Teknologi disinfeksi ruangan khususnya pada ruangan tertutup dengan ventilasi yang kurang baik atau resirkulasi udara tertutup adalah dengan menggunakan kombinasi perlakuan sinar UV dengan filter. Teknologi disinfeksi permukaan benda menggunakan teknik penyemprotan atau pengkabutan larutan disinfektan, sedangkan teknologi dekontaminasi alat pelindung diri dilakukan dengan perlakuan sinar UV atau dengan bahan kimia. Pengembangan dan aplikasi lanjut dari teknologi inaktivasi virus ini akan membantu upaya nasional dalam penanggulangan penyebaran Covid-19.
\end{abstract}

Kata Kunci: Covid-19, disinfeksi, inaktivasi virus, SARS-CoV-2, UV 


\section{PENDAHULUAN}

Penyakit gangguan pernapasan akut yang dikenal dengan nama corona virus disease 2019 (Covid-19) pertama kali dilaporkan muncul di kota Wuhan, ibukota provinsi Hubei, Tiongkok pada akhir tahun 2019 (Wu et al. 2020a). Penyakit ini segera mendapat perhatian dunia karena tingkat penularannya yang tinggi dan menyebabkan kasus kematian beberapa penderita di kota tersebut sehingga pemerintah Tiongkok menerapkan karantina wilayah kota Wuhan secara penuh (lockdown) pada tanggal 23 Januari 2020. Gejala penyakit ini ditandai dengan demam ringan hingga pneumonia yang menyebabkan sindrom pernafasan akut yang dapat berujung pada kematian (Xu et al. 2020b).

Hasil sekuensing metagenomik terhadap sampel cairan saluran pernapasan pasien menunjukkan bahwa Covid-19 disebabkan oleh strain baru virus corona berbasis RNA (Shi et al. 2016) yang awalnya diberi nama 2019-nCoV. Virus ini memiliki $89,1 \%$ kesamaan nukleotida dengan virus penyebab penyakit severe acute respiratory syndrome (SARS) yaitu virus SARS-CoV-1 (Hu et al. 2018), sehingga namanya diubah menjadi virus SARS-CoV-2 (Gorbalenya et al. 2020). Covid-19 saat ini telah menjadi pandemi yang menyebar di hampir seluruh negara di dunia. Berdasarkan data WHO hingga tanggal 28 May 2021, jumlah orang yang terkonfirmasi positif terjangkit Covid-19 di seluruh dunia dilaporkan mencapai 168.599.045 jiwa, dan jumlah kematian mencapai 3.507.477 jiwa (WHO 2021). Diperkirakan angka tersebut akan terus meningkat meskipun telah dilakukan vaksinasi terhadap lebih dari 1,5 milyar penduduk.

Penyebaran virus SARS-CoV-2 diduga sebagian besar melalui percikan air liur (droplet) dan permukaan benda yang terkontaminasi, namun kini semakin banyak bukti bahwa virus ini juga menyebar melalui aerosol (airborne) (Chia et al. 2020; Fennelly 2020; Lednicky et al. 2020; Liu et al. 2020; Nissen et al. 2020; Setti et al. 2020). Berdasarkan penelitian di dua rumah sakit di Wuhan dan beberapa area publik, aerosol virus SARS-CoV-2 terdeteksi di ruang isolasi pasien khususnya di toilet, ruang kantor rumah sakit, dan ruang ganti alat pelindung diri (APD). Sedangkan keberadaan aerosol virus SARS-CoV-2 di area publik sebagian besar tidak terdeteksi, kecuali di area pintu masuk swalayan dimana peluang terjadinya kerumunan meningkat (Liu et al. 2020).

Penularan Covid-19 dapat terjadi pada aktivitas-aktivitas medis maupun bukan medis. Kemungkinan transmisi pada aktivitas medis di antaranya adalah pada saat pengambilan dan setelah penanganan sampel swab pasien. Karena itu, Tang et al. (2020a) menyarankan agar ekstraksi asam nukleat dari sampel swab sebelum analisis RT-PCR dilakukan di laboratorium dengan klasifikasi minimal Biosafety Level 2 (BSL-2), serta menerapkan prosedur kerja yang ketat untuk menghindari terjadinya tumpahan atau kontaminasi dari cairan sampel selama penanganan sampel (Tang et al. 2020b). Transmisi virus ini pada aktivitas medis lainnya dapat terjadi melalui kontak langsung ataupun tidak langsung dengan penderita. Karena penularan virus ini di antaranya melalui aerosol, maka petugas kesehatan yang berinteraksi langsung atau dalam jarak dekat dengan pasien memiliki risiko tinggi tertular. Meskipun pemakaian APD lengkap merupakan prosedur yang diterapkan di berbagai fasilitas kesehatan, namun kejadian petugas kesehatan tertular penyakit Covid-19 terus berlangsung (Ing et al. 2020, Nienhaus dan Hod 2020, lyengar et al. 2020). Penularan ini diduga terjadi melalui kontak tidak langsung dengan permukaan bendabenda yang digunakan oleh penderita, dengan benda-benda yang bersinggungan dengan penderita, atau karena APD yang tidak memadai.

Kasus penularan Covid-19, termasuk di Indonesia, sebagian besar terjadi pada aktivitas bukan medis, yaitu penularan secara langsung dari manusia ke manusia, maupun tidak langsung melalui sentuhan dengan benda-benda yang telah terkontaminasi virus SARS-CoV-2 dalam aktivitas sehari-hari. Penularan Covid-19 secara langsung dari manusia ke manusia saat ini sudah banyak terjadi dalam satu keluarga, yang pada awalnya dilaporkan dalam suatu studi di Tiongkok (Chan et al. 2020a). Penularan penyakit ini secara langsung banyak terjadi pada saat interaksi antar manusia dalam jarak dekat, khususnya saat beraktivitas di dalam ruangan. Penularan Covid-19 dari manusia ke manusia tersebut diduga terjadi 
melalui kontak langsung dengan droplet atau aerosol yang dihasilkan penderita pada saat bersin, batuk, tertawa atau berbincangbincang tanpa menggunakan masker.

Untuk memutus rantai penularan Covid-19 dalam populasi khususnya di tempat dan fasilitas umum dalam ruangan seperti kantor, pusat perbelanjaan, rumah sakit, rumah makan, dan transportasi umum, maka perlu diketahui lebih jauh asal-usul dan karakteristik dari virus ini. Dengan demikian dapat diketahui tindakan pencegahan penularan penyakit ini di antaranya melalui inaktivasi virus. Hingga saat ini, informasi terkait asal-usul dan karakteristik virus SARSCoV-2, serta mekanisme penularan Covid-19 semakin banyak tersedia (Shereen et al. 2020; Li. et al. 2020), termasuk studi epidemiologinya (Xu et al. 2020a; Dong et al. 2020). Namun demikian, masih banyak informasi lain yang diperlukan untuk melengkapi informasi yang sudah ada agar penyakit ini dapat dikendalikan dengan lebih efektif, khususnya terkait dengan metode inaktivasi virus ini.

Metode inaktivasi virus SARS-CoV-2 memegang peranan penting dalam upaya pengendalian penyebaran penyakit Covid-19. Dalam tulisan ini diuraikan mengenai karakteristik virus SARS-CoV-2, dan beberapa metode inaktivasi virus yang dikenal selama ini. Selanjutnya tulisan ini membahas mengenai peluang-peluang teknologi inaktivasi virus yang dapat diaplikasikan di Indonesia, khususnya di berbagai fasilitas umum berdasarkan informasi sifat-sifat virus SARS-CoV-2 dan berdasarkan referensi berbagai aplikasi teknologi inaktivasi virus yang sudah tersedia.

\section{KARAKTERISTIK VIRUS SARS-CoV-2}

Pengetahuan mengenai karakteristik virus SARS-CoV-2 diperlukan dalam upaya inaktivasi virus ini untuk memutus rantai penyebaran Covid-19. Secara genetik virus SARS-CoV-2 termasuk ke dalam jenis $\beta$ corona virus yang sama dengan jenis virus penyebab penyakit SARS dan penyakit Middle East respiratory syndrome (MERS) (Uddin et al. 2020), yang menyerang saluran pernafasan bagian bawah. Selain ketiga jenis virus corona tersebut, virus corona jenis lain yang menjadi penyebab penyakit pada manusia khususnya saluran pernapasan dengan gejala ringan flu dan demam telah dikenal sejak akhir tahun 1960-an (Kahn dan McIntosh 2005).

Seperti halnya virus corona yang lain, karakteristik virus SARS-CoV-2 adalah virus RNA utas tunggal, panjang genom sekitar 30 $\mathrm{kb}$ dan memiliki selubung (envelope) berupa lipid, dimana pada selubung tersebut tersebar glikoprotein membran yang dikenal dengan nama protein S (Kim et al. 2020, Wang et al. 2020). Protein S memiliki struktur berupa tonjolan-tonjolan seperti paku (spikes) yang menjadi wahana virus untuk melekat pada reseptor sel inang (host) dan masuk ke dalam sel inang, sehingga protein ini sangat menentukan tingkat keganasan dari virus ini (Millet dan Whittaker 2015; Walls et al. 2020; Wang et al. 2020). Selain protein S, virus

\section{Coronavirus virion}

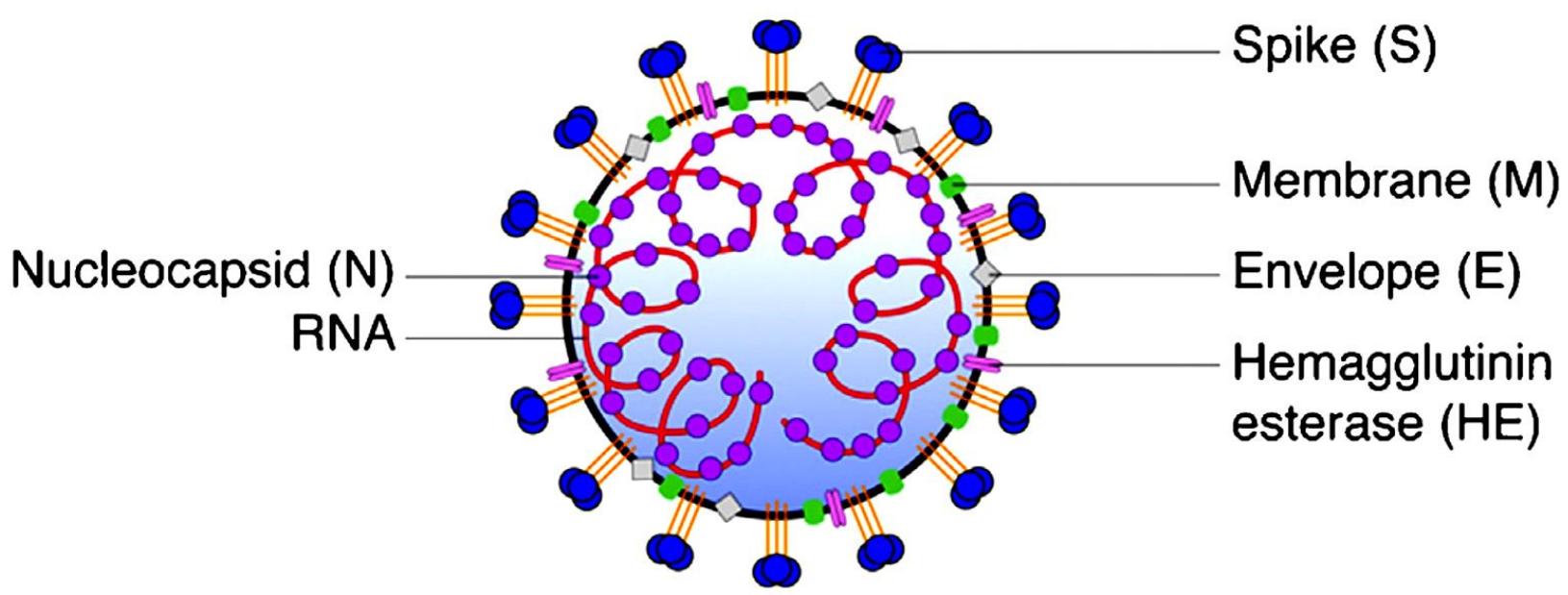

Gambar 1. Struktur virus corona (Millet dan Whittaker 2015) 
SARS-CoV-2 juga memiliki protein struktur lainnya yaitu protein membran (protein $M$ ), protein selubung (protein E) dan nucleocapsid protein (protein N) (Kim et al. 2020; Schoeman dan Fielding 2019). Protein $S$ dari selubung virus corona dijadikan target pembuatan antibodi dalam produksi vaksin karena protein ini menjadi jalan masuk virus ke dalam sel inang. Secara garis besar, struktur virus SARS-CoV-2 ini dapat digambarkan sebagai berikut (Gambar 1).

Berdasarkan karakteristik virus corona di atas, maka target utama untuk inaktivasi virus SARS-CoV-2 adalah dengan merusak struktur selubungnya yang membawa protein $\mathrm{S}, \mathrm{M}$ dan $\mathrm{E}$, merusak struktur protein $\mathrm{N}$, dan struktur RNA. Perlakuan fisik dan kimia diketahui dapat merusak struktur selubung dan struktur proteinnya sehingga virus menjadi tidak aktif. Beberapa metode inaktivasi virus corona dijelaskan lebih jauh di bawah ini.

\section{METODE INAKTIVASI VIRUS}

Penularan Covid-19 dapat terjadi bila virus yang berada dalam droplet atau aerosol tetap aktif atau mempunyai kemampuan untuk menginfeksi penderita baru pada saat masuk ke saluran pernapasan. Oleh karena itu, proses inaktivasi virus SARS-CoV-2, baik yang berada di aerosol maupun pada permukaan benda perlu mendapat perhatian khusus, terutama permukaan benda-benda yang tidak secara langsung digunakan oleh penderita namun dapat menjadi wahana transmisi karena tidak diketahui riwayat kontak benda tersebut sebelumnya. Pada penelitian yang dilakukan oleh van Doremalen et al. (2020) diketahui bahwa SARS-CoV-2 dapat bertahan pada plastik selama 72 jam, stainless steel selama 48 jam, tembaga selama 4 jam dan kardus selama 24 jam. Percobaan lainnya menunjukkan bahwa virus SARS-CoV-2 sudah tidak terdeteksi pada permukaan kertas 3 jam setelah aplikasi, pada permukaan kayu dan baju pada hari ke-2 setelah aplikasi, kaca pada hari ke-3, uang kertas pada hari ke-4, stainless steel dan plastik pada hari ke-7 (Chin et al. 2020). Daya tahan beberapa jenis virus, termasuk virus SARS-CoV-2 pada permukaan benda telah dibahas lebih detail pada tinjauan-tinjauan terdahulu (Aboubakr et al. 2020; Derraik et al. 2020).
Beberapa faktor lingkungan diduga mempengaruhi viabilitas virus SARS-CoV-2, yaitu sinar matahari (sinar ultraviolet, UV), suhu udara, kelembaban dan angin. Metode inaktivasi virus yang dikenal selama ini selain berbasis kimia yaitu dengan menggunakan senyawa-senyawa disinfektan, juga berbasis fisik berdasarkan faktor-faktor lingkungan seperti yang disebut di atas. Namun dari beberapa faktor lingkungan tersebut, hanya sinar UV dan suhu yang saat ini secara praktis digunakan untuk inaktivasi virus. Metode inaktivasi virus menggunakan senyawa kimia, sinar UV dan suhu diuraikan lebih lanjut berikut ini.

\section{Bahan kimia}

Beberapa jenis bahan kimia yang telah diujicoba untuk inaktivasi virus adalah pemutih, deterjen, asam organik, alkohol, dan formaldehid (Lombardi et al. 2008). Sebagian besar bahan-bahan tersebut merupakan bahan yang mudah diperoleh di rumah. Bahan kimia pemutih (hipoklorit) merupakan bahan kimia yang efektif untuk inaktivasi virus. Perlakuan sodium hipoklorit 6.400 ppm selama 1 menit efektif dapat membuat virus pada permukaan kaca menjadi inaktif (Pagat et al. 2007). Hasil percobaan lainnya juga menunjukkan bahwa sodium hipoklorit dengan konsentrasi 750 ppm efektif untuk inaktivasi virus burung H7N2 (Lombardi et al. 2008), sedangkan konsentrasi sodium hipoklorit yang efektif untuk inaktivasi virus H1N1 adalah pada konsentrasi $1 \%$ (Greatorex et al. 2010). Penelitian terbaru menunjukkan bahwa perlakuan dengan larutan pemutih yang diencerkan 100 kali selama 5 menit dapat membuat virus SARSCoV-2 inaktif (Chin et al. 2020). Sedangkan aplikasi larutan pemutih $10 \%$ selama 1 menit efektif membuat sebagian besar virus SARSCoV-2 inaktif, yaitu sebanyak $3,25 \log _{10}$ reduction atau sekitar 99,94\% (Chan et al. 2020b).

Bahan kimia yang paling murah dan mudah diperoleh untuk inaktivasi virus corona yang memiliki selubung adalah sabun/deterjen. Target dari sabun ini adalah merusak dan melarutkan struktur membran lipid yang menjadi selubung virus. Oleh karena itu, salah satu rekomendasi WHO untuk mencegah penyebaran Covid-19 adalah sering mencuci tangan dengan sabun. Inaktivasi virus oleh sabun telah dikenal sejak 
lama. Sabun atau deterjen tidak hanya digunakan untuk inaktivasi virus yang melekat pada tangan, namun juga dapat digunakan untuk aktivasi virus di permukaan benda. Hasil percobaan Lombardi et al. (2008) menunjukkan bahwa deterjen untuk mencuci pakaian yang mengandung peroxygen dapat menginaktivasi virus Avian flu yang memiliki selubung dengan konsentrasi $6 \mathrm{~g} \mathrm{~L}^{-1}$. Deterjen juga umum digunakan dalam kegiatan biologi molekuler khususnya untuk ekstraksi DNA dan protein dari berbagai organisme. Penelitian terbaru menunjukkan bahwa mencuci tangan dengan sabun selama 1 menit mampu menginaktivasi virus SARS-CoV-2 dengan tingkat penurunan ( $\log _{10}$ reduction) sebanyak 2 atau sekitar $85 \%$ (Chan et al. 2020b). Kemampuan sabun untuk menginaktivasi virus SARS-CoV-2 tentunya tergantung dari jenis sabun yang beredar di pasar.

Selain sabun, bahan kimia yang efektif untuk inaktivasi virus SARS-CoV-2 adalah etanol. Etanol merupakan pelarut organik yang digunakan selain untuk membunuh kuman, juga dapat melarutkan lemak. Etanol dapat menginaktivasi virus dengan cara merusak selubung membran virus yang terdiri dari lipid. Etanol banyak digunakan sebagai bahan sanitasi tangan (hand sanitizer) untuk mencegah penyebaran virus SARS-CoV-2. Hand sanitizer yang mengandung etil alkohol $70 \%$ dapat menginaktivasi virus SARS-CoV2 setelah 1 menit dengan $\log _{10}$ reduction sebanyak 2,5 atau sekitar 99,7\% (Chan et al. 2020b). Nilai reduksi dari hand sanitizer ini tidak jauh berbeda dengan hasil yang diperoleh bila menggunakan hand sanitizer dengan komposisi seperti yang dianjurkan oleh WHO (etanol $80 \%$, gliserol 1,45\%, $\mathrm{H}_{2} \mathrm{O}_{2}$ $0,125 \%$ ) yaitu $\log _{10}$ reduction sebesar 2,17 atau sekitar 99,3\% (Chan et al. 2020b).

\section{Sinar ultra violet}

Sinar ultra violet (UV) telah lama diketahui memiliki efek yang mematikan bagi mikroorganisme sehingga digunakan sebagai salah satu metode disinfeksi mikroorganisme dan metode inaktivasi virus. Sinar ultraviolet dapat diklasifikasikan berdasarkan panjang gelombangnya menjadi UV-A (315-400 nm), UV-B (280-315 nm) dan UV-C (100-280 nm). Sinar UV-C memiliki energi tertinggi dan paling efektif menyebabkan partikel virus menjadi inaktif melalui perusakan DNA dan
RNA karena panjang gelombang cahaya yang diabsorbsi maksimum oleh molekul DNA adalah 254 nm (Tseng dan Li 2005). Ketiga jenis sinar UV tersebut secara alami dipancarkan oleh matahari, namun sebagian besar diserap oleh ozon dan uap air di atmosfer (Chou dan Lee 1996) dan hanya sebagian kecil mencapai permukaan bumi (Herndon et al. 2018). Meskipun demikian, sinar UV pada sinar matahari yang mencapai permukaan daratan tetap memiliki efek yang berbahaya bagi mikroorganisme dan virus.

Penelitian terkait inaktivasi virus oleh sinar matahari telah dilaporkan pada virus influenza (Schuit et al. 2020a) dan juga virus SARS-CoV-2 berdasarkan percobaan di laboratorium menggunakan sinar matahari buatan (Ratnesar-Shumate et al. 2020; Schuit et al. 2020b; Dabisch et al. 2021), maupun berdasarkan simulasi data meteorologi (Herman et al. 2021). Dari berbagai hasil studi tersebut dapat disimpulkan bahwa tingkat inaktivasi virus dipengaruhi oleh intensitas cahaya dan lama paparan sinar matahari.

Pengaruh intensitas cahaya matahari terhadap inaktivasi virus SARS-CoV-2 dapat dilihat dari hasil percobaan dengan sinar matahari buatan, dimana $90 \%$ virus menjadi inaktif bila mendapat paparan sinar matahari dengan intensitas $1,6 \mathrm{~W} \mathrm{\textrm {cm } ^ { - 2 }}$ selama 6,8 menit, sedangkan pada intensitas yang lebih rendah yaitu $0,3 \mathrm{~W} \mathrm{~cm}{ }^{-2}$ diperlukan waktu 14,3 menit agar 90\% inaktif (RatnesarShumate et al. 2020). Sinar matahari buatan dengan intensitas $1,6 \mathrm{~W} \mathrm{~cm} \mathrm{~cm}^{-2}$ tersebut mirip dengan kondisi pada tengah hari di musim panas di wilayah sub tropis $40^{\circ} \mathrm{LU}$. Temuan menarik lainnya pada percobaan ini adalah dalam kondisi tanpa ada sinar matahari (kondisi gelap atau dalam ruangan) tidak terjadi degradasi virus yang signifikan. Hal ini juga diperkuat oleh hasil penelitian Schuit et al. (2020b).

Pengaruh lama paparan terhadap tingkat inaktivasi virus ditunjukkan oleh percobaan lain, dimana $50 \%$ virus SARSCoV-2 yang terdapat dalam aerosol dapat diinaktivasi setelah 6 menit penyinaran, dan $90 \%$ virus menjadi inaktif setelah 20 menit penyinaran (Schuit et al. 2020b). Pada percobaan tersebut digunakan spektrum UVA dan UV-B yang menyimulasikan sinar matahari pada tengah hari yang cerah di laut pada latitude $40^{\circ} \mathrm{LU}$ di pertengahan Juni atau 
Tabel 1. Metode inaktivasi virus dengan sinar UV

\begin{tabular}{|c|c|c|c|c|c|c|}
\hline $\begin{array}{l}\text { Jenis } \\
\text { Virus }\end{array}$ & $\begin{array}{l}\text { Panjang } \\
\text { Gelombang }\end{array}$ & $\begin{array}{c}\text { Dosis/ } \\
\text { Intensitas }\end{array}$ & $\begin{array}{c}\text { Waktu } \\
\text { paparan }\end{array}$ & $\begin{array}{l}\text { Persentase } \\
\text { inaktivasi }\end{array}$ & $\begin{array}{l}\text { Aplikasi } \\
\text { Virus }\end{array}$ & Referensi \\
\hline Adenovirus & $254 \mathrm{~nm}$ & $2608 \mu \mathrm{Ws} \mathrm{cm}{ }^{-2}$ & 16,2 detik & $67,1 \%$ & Aerosol & \multirow{2}{*}{ Walker dan Ko (2007) } \\
\hline coronavirus & $254 \mathrm{~nm}$ & $599 \mu \mathrm{Ws} \mathrm{\textrm {cm } ^ { - 2 }}$ & 16,2 detik & $88,8 \%$ & Aerosol & \\
\hline $\begin{array}{l}\text { ssRNA } \\
\text { bacteriophage }\end{array}$ & $254 \mathrm{~nm}$ & $339-423 \mu \mathrm{Ws} \mathrm{cm}{ }^{-2}$ & 0,55 detik & $90 \%$ & Permukaan kaca & Tseng dan Li (2007) \\
\hline $\begin{array}{l}\text { ssDNA } \\
\text { bacteriophage }\end{array}$ & $254 \mathrm{~nm}$ & $444-494 \mu \mathrm{Ws} \mathrm{cm}{ }^{-2}$ & 0,55 detik & $90 \%$ & Permukaan kaca & Tseng dan Li (2007) \\
\hline $\begin{array}{l}\text { dsRNA } \\
\text { bacteriophage }\end{array}$ & $254 \mathrm{~nm}$ & $662-863 \mu \mathrm{Ws} \mathrm{cm}{ }^{-2}$ & 0,55 detik & $90 \%$ & Permukaan kaca & Tseng dan Li (2007) \\
\hline $\begin{array}{l}\text { dsDNA } \\
\text { bacteriophage }\end{array}$ & $254 \mathrm{~nm}$ & $910-1196 \mu \mathrm{Ws} \mathrm{cm}{ }^{-2}$ & 0,55 detik & $90 \%$ & Permukaan kaca & Tseng dan Li (2007) \\
\hline $\mathrm{H} 1 \mathrm{~N} 1$ & $280-800 \mathrm{~nm}$ & $\begin{array}{c}5286 \text { (UV-A), } \\
144(\mathrm{UV}-\mathrm{B}) \mu \mathrm{W} \mathrm{cm}^{-2}\end{array}$ & 2,4 menit & $50 \%$ & Aerosol & Schuit et al. (2020a) \\
\hline SARS-CoV-2 & $\begin{array}{c}254 \text { dan } 365 \\
n m\end{array}$ & $\begin{array}{c}1940 \mu \mathrm{W} \mathrm{cm}^{-2} \text { dan } \\
540 \mu \mathrm{W} \mathrm{cm}-2\end{array}$ & 9 menit & $100 \%$ & 24-well plate & Heilingloh et al. (2020) \\
\hline \multirow{2}{*}{ SARS-CoV-2 } & $200-280 \mathrm{~nm}$ & NA & 1 menit & $99,97 \%$ & Permukaan kaca & Simmons et al. (2020) \\
\hline & $200-280 \mathrm{~nm}$ & NA & 5 menit & $99,98 \%$ & Masker N95 & Simmons et al. (2020) \\
\hline SARS-CoV-2 & $222 \mathrm{~nm}$ & $0.1 \mathrm{~mW} \mathrm{~cm}^{-2}$ & 30 detik & $99,7 \%$ & $\begin{array}{l}\text { Permukaan } \\
\text { polystyrene }\end{array}$ & Kitagawa et al. (20(21) \\
\hline \multirow{2}{*}{ SARS-CoV-2 } & \multirow{2}{*}{$280-315 \mathrm{~nm}$} & $3 \mathrm{~mW} \mathrm{~cm}-2$ & 14,3 menit & $90 \%$ & \multirow{2}{*}{$\begin{array}{l}\text { Air liur (droplet) } \\
\text { buatan pada } \\
\text { permukaan } \\
\text { stainless steel }\end{array}$} & \multirow{2}{*}{$\begin{array}{l}\text { Ratnesar-Shumate et al } \\
(2020)\end{array}$} \\
\hline & & $16 \mathrm{~mW} \mathrm{~cm}^{-2}$ & 6,8 menit & $90 \%$ & & \\
\hline \multirow{3}{*}{ SARS-CoV-2 } & \multirow{3}{*}{$280-400 \mathrm{~nm}$} & $9,4 \mathrm{~mW} \mathrm{~cm}^{-2}$ & 8 menit & $90 \%$ & \multirow{3}{*}{$\begin{array}{l}\text { Aerosol dari air } \\
\text { liur buatan }\end{array}$} & \multirow{3}{*}{ Schuit et al. (2020b) } \\
\hline & & $19,1 \mathrm{~mW} \mathrm{~cm}^{-2}$ & 19 menit & $90 \%$ & & \\
\hline & & $0 \mu \mathrm{W} \mathrm{cm}^{-2}$ & 286 menit & $90 \%$ & & \\
\hline
\end{tabular}

awal Maret/Oktober. Percobaan lainnya menunjukkan bahwa jenis virus corona lebih rentan terhadap sinar UV daripada jenis adenovirus dalam kondisi aerosol (Walker dan Ko 2007).

Berdasarkan hasil-hasil penelitian yang diuraikan di atas, terdapat bukti-bukti ilmiah yang mendukung pendapat bahwa peluang kejadian penularan virus SARS-CoV-2 di luar ruangan yang terpapar sinar matahari langsung lebih rendah dibandingkan dengan di dalam ruangan, karena sinar matahari menyebabkan virus menjadi tidak aktif. Namun demikian, perlu dicatat bahwa inaktivasi virus oleh sinar matahari dipengaruhi pula oleh kondisi cuaca terutama penutupan oleh awan. Karena itu, tingkat inaktivasi virus di luar ruangan oleh sinar matahari akan bervariasi dari hari ke hari. Faktor lingkungan lain juga diyakini memiliki efek terhadap daya tahan virus SARS-CoV-2 di udara bebas, yaitu suhu dan kelembaban udara seperti yang juga akan dibahas dalam makalah ini.

Penyebaran virus SARS-CoV-2 sebagian besar terjadi di dalam ruangan, dan metode inaktivasi virus ini menggunakan sinar UV buatan di dalam ruangan sudah mulai banyak diaplikasikan. Sama seperti sinar matahari, kemampuan inaktivasi virus dari sinar UV buatan ditentukan oleh intensitas cahaya dan lama waktu penyinaran (Duan et al. 2003; Darnell dan Taylor 2006). Karena itu, dalam membuat disain alat untuk inaktivasi virus menggunakan sinar UV, faktor-faktor yang perlu dipertimbangkan adalah jenis sinar UV yang digunakan, intensitas cahaya dan lama waktu paparan. Jenis sinar UV, intensitas cahaya, dan lama waktu paparan yang digunakan untuk inaktivasi berbagai jenis virus dapat dilihat pada Tabel 1.

Spektrum sinar UV yang banyak digunakan berdasarkan rekomendasi berbagai literatur adalah sinar UV-C, dan sebagian kecil lainnya adalah kombinasi sinar UV-C dengan sinar UV-A atau UV-B. Namun demikian, tidak semua panjang gelombang pada spektrum sinar UV-C memiliki efektivitas yang sama dalam menginaktivasi virus. Sinar UV-C pada panjang gelombang $254 \mathrm{~nm}$ memiliki efektivitas yang paling tinggi dalam menginaktivasi virus karena DNA dan RNA menyerap sinar UV ini pada panjang gelombang tersebut (Tseng dan Li 2007).

Studi terbaru terkait inaktivasi virus menunjukkan bahwa virus SARS-CoV-2 
dengan loading $5 \times 10^{6} \mathrm{TCID}_{50} \mathrm{~mL}^{-1}$ dapat diinaktivasi secara keseluruhan dalam waktu 9 menit dengan menggunakan kombinasi sinar UV-A dan UV-C (Heilingloh et al. 2020). Studi lain dengan loading virus SARS-CoV-2 yang sama memperlihatkan waktu yang lebih singkat untuk inaktivasi virus, yaitu $99,7 \%$ virus menjadi inaktif dalam waktu 30 detik setelah pemaparan UV pada panjang gelombang $222 \mathrm{~nm}$ (Kitagawa et al. 2021). Berdasarkan hasil berbagai studi tersebut, secara umum dapat disimpulkan bahwa waktu paparan yang efektif untuk inaktivasi virus SARS-CoV-2 bervariasi mulai dari kurang dari satu menit hingga lebih dari 9 menit. Proses inaktivasi tersebut juga ditentukan oleh kondisi lingkungan serta kondisi permukaan benda yang disinari.

\section{Temperatur dan kelembaban udara}

Kondisi lingkungan yang diduga berpengaruh terhadap viabilitas virus adalah suhu dan kelembaban udara (relative humidity, $\mathrm{RH}$ ). Sebelum terjadi pandemi Covid-19, suhu udara yang hangat dan $\mathrm{RH}$ yang tinggi diyakini mengurangi viabilitas virus SARS-CoV penyebab penyakit SARS yang muncul di tahun 2003 (Chan et al. 2011), sehingga penyakit ini tidak menyebar ke negara tropis seperti Indonesia, Malaysia dan Thailand. Berbeda halnya dengan virus SARS-CoV, virus SARS-CoV-2 yang muncul pada akhir 2019 menunjukkan penyebaran yang cepat ke seluruh dunia termasuk di negara tropis seperti Indonesia, sehingga muncul pertanyaan terkait efek suhu dan $\mathrm{RH}$ terhadap viabilitas virus SARS-CoV-2.

Hasil studi epidemiologi terkait korelasi antara suhu dan $\mathrm{RH}$ terhadap jumlah kasus Covid-19 di berbagai negara menunjukkan hasil yang beragam. Beberapa studi melaporkan korelasi yang negatif antara suhu dan $\mathrm{RH}$ dengan kasus positif Covid-19. Salah satu di antaranya adalah studi yang dilakukan oleh $\mathrm{Wu}$ et al. (2020b) berdasarkan data dari 166 negara, dengan penurunan kasus sebesar $3,08 \%$ dan $0,85 \%$ masing-masing setiap kenaikan suhu $1{ }^{\circ} \mathrm{C}$ dan kenaikan $\mathrm{RH} 1 \%$. Studi lainnya melaporkan hal yang sebaliknya, misalnya studi yang dilakukan oleh Pani et al. (2020) yang melaporkan korelasi positif antara suhu rata-rata harian dan $\mathrm{RH}$ dengan kasus Covid-19 di Singapura. Sedangkan studi lainnya melaporkan tidak ada korelasi antara suhu dan $\mathrm{RH}$ dengan kasus Covid-19 berdasarkan data dari 202 lokasi di 8 negara (Pan et al. 2021). Untuk kasus di Indonesia, hanya suhu rata-rata harian yang memiliki korelasi dengan kasus Covid-19 di Jakarta $\left(r_{s}=0.39 ; p<0.01\right)$ (Tosepu et al. 2020). Hasil studi yang beragam tersebut mengindikasikan bahwa selain faktor lingkungan, juga terdapat faktor lain yang berpengaruh terhadap jumlah kasus Covid19 khususnya terkait dengan kondisi sosial ekonomi masyarakat. Untuk kasus Indonesia, mobilitas dan budaya masyarakat serta tingkat kesadaran masyarakat dalam menerapkan protokol Covid-19 memiliki peran yang signifikan.

Pengaruh suhu dan kelembaban udara pada lingkungan terkendali di dalam ruangan terhadap inaktivasi virus SARSCoV-2 sudah mulai banyak diteliti (Tabel 2). Secara umum, kenaikan suhu mempercepat penurunan viabilitas virus ini. Percobaan Biryukov et al. (2020) menunjukkan bahwa kenaikan suhu dari $24{ }^{\circ} \mathrm{C}$ menjadi $35{ }^{\circ} \mathrm{C}$ menurunkan half-life virus ini $(50 \%$ virus menjadi inaktif) dari 8,5 jam menjadi 2,2 jam. Berdasarkan hasil penelitian Chan et al. (2020b), virus SARS-CoV-2 pada permukaan kaca dalam kondisi kering relatif stabil pada suhu $4^{\circ} \mathrm{C}$ hingga 7 hari, namun pada suhu $30^{\circ} \mathrm{C}$ dan $37^{\circ} \mathrm{C}$ virus ini menjadi tidak aktif masing-masing setelah 3 hari dan 1 hari.

Berbeda halnya dengan temperatur, hasil penelitian Schuit et al (2020b) menunjukkan bahwa $\mathrm{RH}$ tidak memiliki pengaruh langsung terhadap inaktivasi virus SARS-CoV-2. Namun demikian, hasil penelitian lain mengindikasikan bahwa $\mathrm{RH}$ memiliki pengaruh terhadap efektivitas sinar UV ataupun temperatur dalam inaktivasi virus. Studi oleh Tseng dan Li (2007) menunjukkan bahwa inaktivasi beberapa jenis virus memerlukan dosis UV yang lebih tinggi (dalam $\mu \mathrm{Ws} \mathrm{cm}^{-2}$ ) pada $\mathrm{RH}$ yang lebih tinggi, yaitu $\mathrm{RH} 85 \%$ dibandingkan dengan $\mathrm{RH} 55 \%$. Penelitian lain menunjukkan bahwa $\mathrm{RH}$ berpengaruh terhadap inaktivasi virus SARS-CoV-2 pada suhu $24{ }^{\circ} \mathrm{C}$, sedangkan pada suhu yang lebih tinggi yaitu $35^{\circ} \mathrm{C}, \mathrm{RH}$ tidak berpengaruh (Biryukov et al. 2020). Pada suhu $24{ }^{\circ} \mathrm{C}$, peningkatan $\mathrm{RH}$ dari $20 \%$ menjadi $80 \%$ mempercepat half-life virus SARS-CoV-2 dari 15,3 jam menjadi 8,3 jam (Biryukov et al. 2020). 


\section{PELUANG TEKNOLOGI}

Hingga saat ini, pertambahan penderita Covid-19 di Indonesia yang terkonfirmasi setiap hari masih terhitung tinggi dengan jumlah penderita positif harian hingga tanggal $28 \mathrm{Mei}$
2021 diatas 6000 orang per hari. Klaster penularan baru akhir-akhir ini banyak bermunculan dari perkantoran. Penyebaran virus yang tinggi di perkantoran ini diduga selain berasal dari droplet, juga berasal dari aerosol yang dihasilkan oleh penderita positif Covid-19, yang

Tabel 2. Pengaruh suhu dan kelembaban $(\mathrm{RH})$ terhadap inaktivasi virus

\begin{tabular}{|c|c|c|c|c|c|}
\hline \multirow{2}{*}{ Jenis Virus } & \multicolumn{2}{|c|}{ Perlakuan } & \multirow{2}{*}{ Sampel } & \multirow{2}{*}{ Hasil } & \multirow{2}{*}{ Referensi } \\
\hline & Suhu & $\mathrm{RH}$ & & & \\
\hline \multirow{2}{*}{ SARS-CoV-2 } & $56^{\circ} \mathrm{C}, 30 \mathrm{~min}$ & \multirow{2}{*}{ ND } & \multirow{2}{*}{ nasofaring } & $\log _{10}$ reduction $>5$ & \multirow{2}{*}{ - Pastorino et al. (2020) } \\
\hline & $60^{\circ} \mathrm{C}, 60 \mathrm{~min}$ & & & $\log _{10}$ reduction $>5$ & \\
\hline \multirow{2}{*}{ SARS-CoV-2 } & $56^{\circ} \mathrm{C}, 30 \mathrm{~min}$ & \multirow{2}{*}{ ND } & \multirow{2}{*}{$\begin{array}{c}\text { Virus di } \\
\text { medium kultur }\end{array}$} & $\log _{10}$ reduction 4,6 & \multirow{2}{*}{ Chin et al. (2020) } \\
\hline & $70^{\circ} \mathrm{C}, 5 \mathrm{~min}$ & & & $\log _{10}$ reduction 3,3 & \\
\hline SARS-CoV-2 & $24^{\circ} \mathrm{C}$ & $\begin{array}{c}20,40 \\
60,80 \%\end{array}$ & $\begin{array}{l}\text { virus dalam } \\
\text { liur buatan }\end{array}$ & $\begin{array}{l}\text { Half life 15,33; 11,52; } \\
\text { 9,15; dan 8,33 jam }\end{array}$ & Biryukov et al. (2020) \\
\hline SARS-CoV-2 & $35^{\circ} \mathrm{C}$ & $\begin{array}{c}20,40 \\
60 \%\end{array}$ & $\begin{array}{l}\text { Virus dalam } \\
\text { liur buatan }\end{array}$ & $\begin{array}{c}\text { Half life } 7,33,7,52 \\
\text { dan } 2,26 \text { jam }\end{array}$ & Biryukov et al. (2020) \\
\hline SARS-CoV-2 & $20^{\circ} \mathrm{C}$ & $\begin{array}{c}37 \text { dan } \\
53 \%\end{array}$ & $\begin{array}{l}\text { Aerosol liur } \\
\text { buatan }\end{array}$ & $\begin{array}{c}\text { pengaruh } \mathrm{RH} \text { tidak } \\
\text { signifikan }\end{array}$ & Schuit et al. (2020b) \\
\hline SARS-CoV-2 & $\begin{array}{l}4^{\circ} \mathrm{C}, 25^{\circ} \mathrm{C} \\
30^{\circ} \mathrm{C}, 37^{\circ} \mathrm{C}\end{array}$ & ND & $\begin{array}{l}\text { Virus } \\
\text { dikeringkan } \\
\text { atau di } \\
\text { larutan } \\
\text { medium } \\
\text { kultur }\end{array}$ & $\begin{array}{l}\text { Kering: Hari ke-1, } \log _{10} \\
\text { reduction }>4\left(37^{\circ} \mathrm{C} \text {, Hari }\right. \\
\text { ke-1), > } 3\left(30^{\circ} \mathrm{C}\right),<1(25 \\
\left.{ }^{\circ} \mathrm{C}\right),>1\left(4^{\circ} \mathrm{C}\right) \\
\text { Larutan: Hari ke-1, } \log _{10} \\
\text { reduction }>3\left(37^{\circ} \mathrm{C}\right),>1 \\
\left(30^{\circ} \mathrm{C}\right),<1\left(25^{\circ} \mathrm{C}\right), 0\left(4^{\circ} \mathrm{C}\right)\end{array}$ & Chan et al. (2020b) \\
\hline \multirow{2}{*}{ SARS-CoV } & \multirow{2}{*}{$\begin{array}{l}4^{\circ} \mathrm{C}, 25^{\circ} \mathrm{C} \\
30^{\circ} \mathrm{C}, 37^{\circ} \mathrm{C}\end{array}$} & & \multirow{2}{*}{$\begin{array}{l}\text { Virus } \\
\text { dikeringkan } \\
\text { atau di } \\
\text { medium } \\
\text { kultur }\end{array}$} & $\begin{array}{l}\text { Kering: Hari ke-1, } \log _{10} \\
\text { reduction }>4\left(37^{\circ} \mathrm{C}\right),>2 \\
\left(30^{\circ} \mathrm{C}\right),>1\left(25^{\circ} \mathrm{C}\right), 1\left(4^{\circ} \mathrm{C}\right)\end{array}$ & \multirow{2}{*}{ Chan et al. (2020b) } \\
\hline & & & & $\begin{array}{l}\text { Larutan: Hari ke-1, } \log _{10} \\
\text { reduction }>3\left(37^{\circ} \mathrm{C}\right),>1 \\
\left(30^{\circ} \mathrm{C}\right), 0\left(25^{\circ} \mathrm{C}, 4^{\circ} \mathrm{C}\right)\end{array}$ & \\
\hline $\mathrm{H} 1 \mathrm{~N} 1$ & $20^{\circ} \mathrm{C}$ & $\begin{array}{l}20 \text { dan } \\
70 \%\end{array}$ & $\begin{array}{c}\text { Aerosol } \\
\text { medium kultur }\end{array}$ & $\begin{array}{l}\text { pengaruh } \mathrm{RH} \text { tidak } \\
\text { signifikan }\end{array}$ & Schuit et al. (2020a) \\
\hline
\end{tabular}

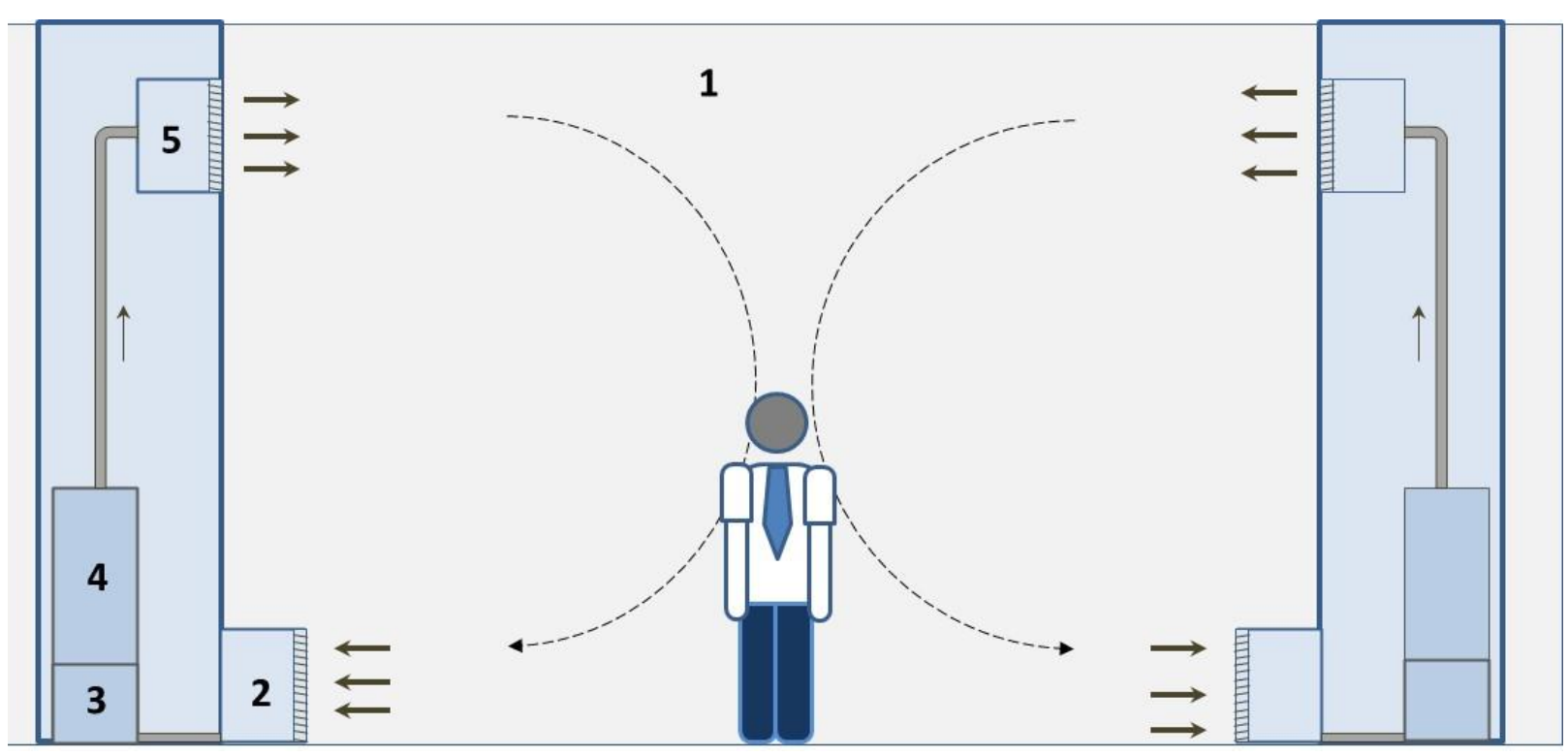

Gambar 2. Sistem disinfeksi ruangan dengan sinar UV dan filtrasi, dan sistem sirkulasi ruangan (Keterangan : $1=$ udara dalam ruangan; 2 = lubang udara masuk dengan filter; 3 = blower, 4 = sistem UV; 5 = sistem fliter) 
menyebar di dalam ruangan karena ventilasi udara yang kurang baik, atau sistem sirkulasi udara yang tertutup (Morawska et al. 2020, Somsen et al. 2020, Tang et al. 2020).

Upaya untuk menurunkan laju penyebaran penyakit ini di antaranya adalah dengan menerapkan protokol kesehatan Covid-19 seperti penggunaan masker, disinfeksi tangan menggunakan larutan disinfektan atau mencuci tangan dengan sabun terutama bila berada di area umum, dan menjaga jarak. Upaya lainnya adalah melalui inovasi teknologi khususnya teknologi inaktivasi virus di udara dalam ruangan, di permukaan benda, atau pada alat pelindung diri. Teknologi ini dapat diaplikasikan di rumah sakit, perkantoran atau tempat umum. Beberapa peluang inovasi teknologi tersebut yaitu teknologi disinfeksi ruangan, teknologi disinfeksi permukaan benda dan teknologi disinfeksi APD dijelaskan sebagai berikut.

\section{Teknologi disinfeksi ruangan}

Teknologi disinfeksi ruangan telah dikembangkan oleh beberapa pihak dan juga telah disarankan untuk digunakan dalam pencegahan virus SARS-CoV-2 (misalnya Morawska et al. 2020; Nardell 2021), namun penerapannya secara luas tergantung dari investasi yang dikeluarkan. Teknologi ini menggunakan prinsip disinfeksi dengan sinar UV yang dikombinasikan dengan sistem filtrasi udara menggunakan filter HEPA dan sistem sirkulasi udara yang membantu mengurangi peluang penyebaran virus dalam ruangan.

Secara garis besar, sistem disinfeksi ruangan tersebut dapat dilihat pada Gambar 2. Dalam sistem ini, udara dalam ruangan (Gambar 2 No.1) disedot masuk ke dalam sistem melalui lubang udara yang ada di atas lantai (No.2) dengan bantuan pompa udara (No. 3). Lubang masuk udara tersebut dilengkapi dengan filter yang dapat diganti secara berkala. Selanjutnya, udara dialirkan ke dalam kotak UV (No. 4), dimana udara tersebut disterilisasi menggunakan sinar UVC selama periode waktu tertentu. Setelah itu udara yang telah didisinfeksi dialirkan ke kotak 5 yang berisi filter HEPA. Udara bersih tersebut dialirkan ke dalam ruangan dengan arah horizontal melalui lubang udara yang ditempatkan di bagian atas dinding ruangan pada kecepatan tertentu, atau dipasang pada langit-langit yang mengarah ke bawah.
Dengan sistem ini, terjadi sirkulasi udara bersih dari bagian atas ruangan menuju ke bagian bawah ruangan. Jumlah lubang udara bersih untuk satu ruangan dapat disesuaikan dengan luas ruangan dan kapasitas sistem disinfeksi udara yang digunakan. Penempatan HEPA berdasarkan literatur dan sumber-sumber lainnya (termasuk aplikasi di rumah sakit) bervariasi, sebagian menempatkan HEPA filter upstream blower (Secretariat MA 2005) dan lampu UV, ada yang downstream blower atau kedua-duanya (Nardell 2021). Terlepas dari penempatan filter HEPA tersebut, hal penting yang perlu dicapai adalah efisiensi penyisihan partikel virus dari udara yang dialirkan ke dalam ruangan dan jumlah udara yang dialirkan ke dalam ruangan.

Teknologi disinfeksi ruangan ini dapat diaplikasikan pada ruangan secara permanen, atau secara portabel. Keuntungan penggunaan perangkat portabel adalah mudah dipindah dan tidak perlu membuat instalasi khusus di dinding atau merubah disain bangunan, namun kekurangannya adalah kapasitasnya terbatas untuk pemakaian ruangan yang kecil.

Beberapa hal yang menjadi catatan dalam pengembangan dan pemasaran produk teknologi inaktivasi virus ini adalah efektivitas dari alat yang dikembangkan. Efektivitas alat ini perlu diuji secara ilmiah agar klaim dari alat ini dapat dipertanggungjawabkan mengingat risiko penyebaran penyakit ini yang cukup tinggi. Variabel penentu dari aplikasi teknologi ini di antaranya adalah lama waktu paparan sinar UV dan volume udara bersih yang dialirkan ke dalam ruangan per jam (air change per hour, ACH) (Nardell 2021). Hingga kini belum ada standar yang dikeluarkan oleh lembaga resmi terkait dengan besaran $\mathrm{ACH}$ yang diperlukan untuk desinfeksi ruangan terkait Covid-19. Standar ASHRAE untuk nilai $\mathrm{ACH}$ pada fasilitas kesehatan bergantung pada fungsi ruangan, misalnya ruangan isolasi pasien, ruang operasi dan ruang perawat masingmasing sebesar 12, 20 dan $4 \mathrm{ACH}$ (Hermans et al. 2008). Sedangkan CDC menyarankan 6-12 ACH untuk ruang perawatan dan isolasi (Secretariat MA 2005).

Studi efektivitas teknologi ini dalam pencegahan penularan Covid-19 di lingkungan rumah sakit dan perkantoran belum tersedia. Berdasarkan studi Miller- 
Leiden et al. (1996) terkait pencegahan sebaran penyakit TB, diperoleh hasil bahwa penurunan konsentrasi partikel infeksius dalam ruangan yang disirkulasi dengan udara bersih setelah melewati filter HEPA bervariasi antara $30-90 \%$, tergantung dari penempatan lubang udara bersih yang masuk ke ruangan. Penurunan konsentrasi ini terjadi melalui mekanisme pengenceran udara yang terkontaminasi (Miller-Leiden et al. 1996).

Aplikasi teknologi disinfeksi ruangan ini perlu mempertimbangkan beberapa kondisi agar udara dapat mengalir melalui filter HEPA sesuai kebutuhan, misalnya kriteria filter HEPA yang digunakan, kapasitas blower, dan differential pressure yang perlu diwujudkan. Jenis HEPA yang digunakan berdasarkan standar CDC adalah yang memiliki efisiensi penyisihan partikel $\geq$ $0,3 \mu \mathrm{m}$ sebesar $99,97 \%$ (Secretariat MA 2005). Dalam pemilihan jenis filter HEPA, pengguna perlu memperhatikan beberapa sertifikat standar yang tercantum pada produk, seperti US Institute of Environmental Sciences and Technology (IEST-RP-CC001.6) atau the International Organization for Standardization (ISO 29463) (Christopherson et al. 2019). Kapasitas blower ditentukan berdasarkan luas ruangan yang dilayani, nilai $\mathrm{ACH}$ dan besaran differential pressure. Besaran differential pressure menurut standar ASHRAE 170 adalah $+2,5 \mathrm{~Pa}$ (Hermans et al. 2008).

Isu lain yang perlu mendapat perhatian adalah penanganan dalam perawatan filter HEPA. Filter ini berfungsi menyaring partikelpartikel di udara termasuk partikel virus agar diperoleh udara bebas virus. Dengan demikian, filter HEPA yang digunakan di rumah sakit atau fasilitas umum dapat diduga banyak terakumulasi partikel virus SARSCoV-2. Penelitian terbaru menunjukkan bahwa virus SARS-CoV-2 ditemukan pada sistem filter HEPA di rumah sakit, meskipun kemampuan partikel virus yang ditemukan pada filter HEPA tersebut untuk menginfeksi non-penderita Covid-19 tidak diketahui (Nissen et al. 2020). Oleh karena itu, perawatan filter HEPA perlu ditangani secara khusus untuk menghindari petugas terkontaminasi virus ini dari filter HEPA yang telah terpakai.

Teknologi desinfeksi ruangan lainnya yang disarankan untuk pencegahan penyebaran Covid-19 adalah desinfeksi ruangan dengan sinar UV langsung (Nardell 2021). Pada teknologi ini, sinar UV dipancarkan dari lampu di langit-langit ruangan atau bagian atas dinding ruangan, dan dikombinasikan dengan kipas angin untuk sirkulasi udara (Nardell dan Nathavitharana 2020; Morawska et al. 2020; Nardell 2021). Aplikasi teknologi ini secara luas masih menghadapi isu keamanan, khususnya bila ruangan digunakan untuk aktivitas manusia pada saat lampu UV dinyalakan. Untuk mengurangi risiko tersebut, beberapa fasilitas umum menggunakan pelindung di bawah lampu untuk menghindari sinar UV langsung mengenai personil yang ada di dalam ruangan.

\section{Teknologi disinfeksi permukaan benda}

Teknologi disinfeksi permukaan benda yang banyak digunakan untuk mencegah penularan SARS-CoV-2 adalah penyemprotan dengan larutan disinfektan, dan aplikasi sinar UV (Choi et al. 2021). Penyemprotan larutan disinfektan seperti hipoklorit dan peroksida di berbagai fasilitas umum untuk mencegah penularan SARSCoV-2 dalam prakteknya banyak dilakukan secara manual. Penyemprotan dengan larutan peroksida atau larutan hipoklorit telah dilaporkan efektif untuk dekontaminasi permukaan yang halus tanpa perlu diseka (Cadnum et al. 2015). Sebelum dilakukan penyemprotan, permukaan benda disarankan untuk dibersihkan terlebih dahulu dari debu atau kotoran organik dan anorganik agar larutan disinfektan bekerja lebih efektif (misalnya oleh Chen dan O'Keeffe 2020). Akhir-akhir ini dikembangkan teknologi electrostatic spray yang tidak memerlukan pembersihan sebelum penyemprotan (Cadnum et al. 2020). Teknologi ini menggunakan elektrode yang ditempatkan dalam nozel. Ketika disemprotkan, partikel disinfektan berukuran 40-80 $\mu \mathrm{m}$ menjadi bermuatan positif atau negatif, sehingga lebih mudah menempel pada permukaan benda. Teknologi ini merupakan pelengkap dari teknik disinfeksi permukaan benda secara manual, dengan tujuan untuk disinfeksi permukaan benda dalam ruangan atau fasilitas umum yang luas lebih cepat dan untuk disinfeksi permukaan yang sulit dijangkau. 
Teknologi lain yang menggunakan larutan disinfektan yang berpotensi diaplikasikan adalah teknologi pengkabutan (fogging) dengan larutan hidrogen peroksida. Teknologi ini telah lama digunakan di industri pengolahan makanan dan farmasi (Masotti et al. 2019) dan kemudian di rumah sakit (Boyce 2009). Perangkat fogging tersebut bisa dipasang di permukaan benda ataupun portabel. Partikel disinfektan yang dihasilkan berupa aerosol berukuran sangat kecil, yaitu 1-10 $\mu \mathrm{m}$ (disebut dry vapour) ataupun $>10$ $\mu \mathrm{m}$ (disebut micro-condensation) (Chen dan O'Keeffe 2020). Karena bersifat aerosol, maka partikel disinfektan bisa lebih lama berada di udara sehingga sekaligus melakukan disinfeksi udara dan permukaan benda. Teknologi ini juga merupakan pelengkap dari disinfeksi permukaan benda yang dilakukan secara rutin, yang dilakukan pada saat pergantian pasien (Boyce 2009) atau secara berkala sebulan sekali (Masotti et al. 2019). Efektivitas teknologi ini dalam mencegah penularan virus SARS-CoV-2 masih perlu diuji lebih lanjut, meskipun efektivitasnya dalam inaktivasi virus lain dan mikroorganisme telah banyak dilaporkan (Ahmed dan Mulder 2021).

Dekontaminasi permukaan benda dengan sinar UV dalam ruangan dapat dilakukan menggunakan lampu UV yang terpasang di langit-langit atau dinding bagian atas, atau menggunakan alat portabel yang mudah dibawa. Dekontaminasi permukaan benda dalam ruangan dengan perangkat sinar UV yang dipasang di langit-langit ruangan dilakukan bersamaan dengan desinfeksi udara ruangan. Efektivitas teknologi ini terhadap penanggulangan penyebaran Covid-19 masih belum diketahui, namun berdasarkan hasil percobaan menggunakan hewan marmut pada penyakit TB, tingkat penularan penyakit TB dapat diturunkan hingga $80 \%$ dengan rata-rata tingkat radiasi UV 5-7 $\mu \mathrm{W} \mathrm{cm}$ c $^{-2}$ (Mphaphlele et al. 2015).

Disinfeksi permukaan benda menggunakan perangkat sinar UV portabel mulai banyak diusulkan sejak pandemi Covid-19 berlangsung. Prinsip dari teknologi ini adalah menggunakan paparan sinar UV untuk inaktivasi virus yang melekat pada permukaan benda-benda yang sulit dibersihkan dengan larutan disinfektan. Teknologi ini telah lama diaplikasikan di mobil ambulans dan helikopter ambulans untuk mencegah penyebaran penyakit yang ditularkan melalui udara (Schulz-Stübner et al. 2019). Perangkat portabel ini telah banyak beredar di pasar, dan studi terkait efektivitas berbagai perangkat portabel tersebut untuk inaktivasi virus SARS-CoV-2 sudah dilaporkan di Inggris (Khazova et al. 2021). Secara umum, sebagian perangkat yang diuji memiliki kemampuan inaktivasi virus hingga $90 \%$, namun risiko terpapar sinar UV juga tinggi. Penggunaan perangkat tersebut tanpa dilengkapi fitur keamanan dari pabrik atau pelindung tubuh yang memadai memiliki risiko terpapar radiasi UV yang menyebabkan kulit terbakar dan kerusakan mata (Byrns et al. 2017; Khazova et al. 2021).

\section{Teknologi disinfeksi APD}

Pada periode awal pandemi (triwulan pertama tahun 2020), terjadi kelangkaan APD, baik di negara-negara berkembang maupun di negara-negara maju seperti yang dilaporkan oleh Organisasi Kesehatan Dunia (WHO 2020). Dalam kondisi tersebut, penggunaan kembali (reuse) APD muncul sebagai satu alternatif solusi khususnya bagi tenaga kesehatan untuk mengatasi kelangkaan APD. Jenis APD yang umumnya menjadi target untuk digunakan kembali adalah gaun medis dan masker, karena paling banyak dibutuhkan dalam jumlah besar.

Teknologi disinfeksi APD dikembangkan agar dapat dipakai ulang pada saat ketersediaannya terbatas di masa pandemi. Metode yang disarankan untuk digunakan dalam dekontaminasi APD yaitu menggunakan uap hidrogen peroksida atau perlakuan sinar UV karena hasil dekontaminasi lebih konsisten, dan efek yang lebih sedikit terhadap segel pelindung respirator dan efisiensi filtrasi (RodriguezMartinez et al. 2020, Steinberg et al. 2020). Efektivitas dari aplikasi uap hidrogen peroksida untuk desinfeksi tiga jenis bakteri patogen pada APD seperti gaun medis, face shield dan respirator N95 telah dilaporkan oleh Saini et al. (2020). Pada percobaan tersebut, aplikasi uap hidrogen peroksida dengan konsentrasi optimum $8 \%$ selama 10 menit efektif menghilangkan bakteri yang berada pada permukaan gaun medis tanpa merusak struktur bahan APD yang diuji. 
Efektivitas dari aplikasi sinar UV terhadap inaktivasi virus SARS-CoV-2 dapat diketahui dari hasil percobaan pada respirator N95. Pada percobaan tersebut, perlakuan sinar UV selama 5 menit pada permukaan respirator N95 menyebabkan inaktivasi virus SARS-CoV-2 sebesar 99,97\% (Simmons et al. 2020).

Kedua metode tersebut memiliki kelebihan dan kekurangan masing-masing. Inaktivasi virus yang melekat pada permukaan respirator N95 dengan sinar UV lebih sederhana dan dapat langsung digunakan kembali setelah perlakuan. Dekontaminasi respirator N95 dengan menggunakan larutan bahan kimia selain membutuhkan waktu untuk mengeringkannya, juga residu bahan kimia yang tertinggal di APD berisiko membahayakan kesehatan pemakainya. Namun metode dekontaminasi respirator dengan metode sinar UV memiliki kelemahan karena ada kemungkinan sinar UV tidak masuk ke lapisan dalam respirator karena terhalang lapisan luar.

Beberapa hal yang perlu diperhatikan dalam aplikasi teknologi desinfeksi APD menggunakan sinar UV adalah dosis dan waktu paparan. Waktu paparan yang terlalu singkat menyebabkan inaktivasi virus menjadi tidak efektif, namun waktu paparan yang terlalu lama menyebabkan kerusakan material polimer sehingga menurunkan kemampuan filtrasi dari respirator. Gelombang pendek UV pada $254 \mathrm{~nm}$ yang dioperasikan dengan dosis maksimal $950 \mathrm{~J}$ $\mathrm{m}^{-2}$ diketahui tidak mengubah kemampuan filtrasi respirator terhadap virus dan tidak mengubah struktur dari filter (Boskoski et al. 2020).

\section{KESIMPULAN}

Hingga saat ini, penyebaran penyakit Covid-19 masih meluas di banyak negara termasuk Indonesia. Cara yang tersedia untuk mengurangi penyebaran penyakit Covid-19 adalah dengan menggunakan masker, mencuci tangan setelah menyentuh benda-benda, menghindari kerumunan dan menjaga jarak. Namun cara ini dirasa masih belum cukup mengingat kondisi sosial ekonomi masyarakat yang belum sepenuhnya mendukung. Upaya vaksinasi terhadap penyakit Covid-19 saat ini masih berlangsung, sehingga upaya pencegahan penyebaran penyakit ini melalui aplikasi teknologi inaktivasi virus masih terus ditingkatkan. Pemilihan jenis teknologi inaktivasi virus sangat bergantung pada jenis pemakai (individu atau sekelompok orang), lokasi penggunaannya (ruang tertutup tanpa ventilasi, ruangan berventilasi, ruang tunggu), luas ruangan, kemudahan dalam aplikasi dan pengoperasian, serta berbiaya murah. Aplikasi teknologi inaktivasi virus berbasis sinar UV dan penyemprotan larutan disinfektan menjadi alternatif utama teknologi, khususnya di ruangan tertutup dengan ventilasi yang tidak memadai atau yang menggunakan sistem resirkulasi. Pengembangan lebih lanjut dan aplikasi teknologi ini secara luas diharapkan dapat membantu mengurangi penyebaran penyakit ini di Indonesia.

\section{DAFTAR PUSTAKA}

Aboubakr HA, Sharafeldin TA, Goyal SM (2020) Stability of SARS-CoV-2 and other coronaviruses in the environment and on common touch surfaces and the influence of climatic conditions: A review. Transbound Emerg Dis 68: 296312. doi: 10.1111/tbed.13707

Ahmed R, Mulder R (2021) A Systematic review on the efficacy of vaporized hydrogen peroxide as a non-contact decontamination system for pathogens associated with the dental environment. Int J Environ Res Public Health 18: 4748. doi: 10.3390/ijerph18094748

Biryukov J, Boydston JA, Dunning RA, Yeager JJ, Wood S, Reese AL, Ferris A, Miller D, Weaver W, Zeitouni NE, Phillips A, Freeburger D, Hooper I, Ratnesar-Shumate $S$, Yolitz J, Krause M, Williams G, Dawson DG, Herzog A, Dabisch $P$, Wahl $V$, Hevey MC, Altamura LA (2020) Increasing temperature and relative humidity accelerates inactivation of SARS-CoV2 on surfaces. mSphere 5: e00441-20. doi: $10.1128 / \mathrm{mSphere} .00441-20$

Boskoski I, Gallo C, Wallace MB, Costamagna G (2020) COVID-19 pandemic and personal protective equipment shortage : protective efficacy comparing masks and scientific methods for respirator reuse. 
Gastrointest Endosc 92: 519-523. doi: 10.1016/j.gie.2020.04.048

Boyce JM (2009) New approaches to decontamination of rooms after patients are discharged. Infect Control Hosp Epidemiol 30: 515-517. doi: 10.1086/598999

Byrns G, Barham B, Yang L, Webster K, Rutherford G, Steiner G, Petras D, Scannell M (2017) The uses and limitations of a hand-held germicidal ultraviolet wand for surface disinfection. J Occup Environ Hyg 14: 749-757. doi: 10.1080/15459624.2017.1328106

Cadnum JL, Jencson AL, Livingston $\mathrm{SH}, \mathrm{Li}$ DF, Redmond SN, Pearlmutter B, Wilson BM, Donskey CJ (2020) Evaluation of an electrostatic spray disinfectant technology for rapid decontamination of portable equipment and large open areas in the era of SARS-CoV-2. Am J Infect Control 48: 951-954. 10.1016/j.ajic.2020.06.002

Cadnum JL, Mana TSC, Jencson A, Thota P, Kundrapu S, Donskey CJ (2015) Effectiveness of a hydrogen peroxide spray for decontamination of soft surfaces in hospitals. Am J Infect Control 43: 1357-1359. doi: 10.1016/j.ajic.2015.07.016

Chan JFW, Yuan S, Kok KH, To KKW, Chu $H$, Yang J, Xing F, Liu J, Yip CCY, Poon RWS, Tsoi HW, Lo SKF, Chan KH, Poon VKM, Chan WM, Ip JD, Cai JP, Cheng VCC, Chen $\mathrm{H}$, Hui CKM, Yuen KY (2020a) A familial cluster of pneumonia associated with the 2019 novel coronavirus indicating person-toperson transmission: A study of a family cluster. Lancet 395: 514-523. doi: 10.1016/S0140-6736(20)30154-9

Chan KH, Peiris JSM, Lam SY, Poon LLM, Yuen KY, Seto WH (2011) The effects of temperature and relative humidity on the viability of the SARS coronavirus. Adv Virol 2011: 734690. doi: 10.1155/2011/734690

Chan $\mathrm{KH}$, Sridhar S, Zhang RR, Chu H, Fung AYF, Chan G, Chan JFW, To KKW, Hung IFN, Cheng VCC, Yuen KY (2020b) Factors affecting stability and infectivity of SARS-CoV-2. J Hosp Infect 106: 226-231. doi: 10.1016/j.jhin.2020.07.009
Chen T, O'Keeffe J (2020) COVID-19 in indoor environments - Air and surface disinfection measures. National Collaborating Center for Environmental Health 2020: 1-25

Chia PY, Coleman KK, Tan YK, Ong SWX, Gum M, Lau SK, Lim XF, Lim AS, Sutjipto S, Lee PH, Son TT, Young BE, Milton DK, Gray GC, Schuster S, Barkham T, De PP, Vasoo S, Chan M, Ang BSP, Tan BH, Leo YS, Ng OT, Wong MSY, Marimuthu K, Lye DC, Lim $P L$, Lee CC, Ling LM, Lee L, Lee TH, Wong CS, Sadarangani S, Lin RJ, Ng DHL, Sadasiv M, Yeo TW, Choy CY, Tan GSE, Dimatatac F, Santos IF, Go CJ, Chan YK, Tay JY, Tan JYL, Pandit $\mathrm{N}$, Ho $\mathrm{BCH}$, Mendis $\mathrm{S}$, Chen $\mathrm{YYC}$, Abdad MY, Moses D (2020) Detection of air and surface contamination by SARS-CoV-2 in hospital rooms of infected patients. Nat Commun 11: 2800. doi: 10.1038/s41467-020-166702

Chin AWH, Chu JTS, Perera MRA, Hui KPY, Yen $\mathrm{H}-\mathrm{L}$, Chan MCW, Peiris M, Poon LLM (2020) Stability of SARS-CoV-2 in different environmental conditions. Lancet Microbe 1: e10. doi: 10.1016/s2666-5247(20)30003-3

Choi $\mathrm{H}$, Chatterjee P, Lichtfouse E, Martel JA, Hwang $M$, Jinadatha $C$, Sharma VK (2021) Classical and alternative disinfection strategies to control the COVID-19 virus in healthcare facilities: A review. Environ Chem Lett 19: 19451951. doi: 10.1007/s10311-021-01180-4

Chou M-D, Lee K-T (1996) Parameterizations for the absorption of solar radiation by water vapor and ozone. J Atmos Sci 53: 1203-1208. doi: 10.1175/15200469(1996)053<1203:pftaos>2.0.co;2.

Christopherson DA, Yao WC, Lu M, Vijayakumar R, Sedaghat AR (2019) High-Efficiency Particulate Air Filters in the Era of COVID-19: Function and Efficacy.1-3. doi:10.1177/019459982 0941838.

Dabisch P, Schuit M, Herzog A, Beck K, Wood S, Krause M, Miller D, Weaver W, Freeburger D, Hooper I, Green B, Williams G, Holland B, Bohannon J, Wahl V, Yolitz J, Hevey M, RatnesarShumate S (2021) The influence of temperature, humidity, and simulated 
sunlight on the infectivity of SARS-CoV2 in aerosols. Aerosol Sci Technol 55: 142-153. doi:

10.1080/02786826.2020.1829536

Darnell MER, Taylor DR (2006) Evaluation of inactivation methods for severe acute respiratory syndrome coronavirus in noncellular blood products. Transfusion 46: 1770-1777. doi: 10.1111/j.15372995.2006.00976.x

Derraik JGB, Anderson WA, Connelly EA, Anderson YC (2020) Rapid review of SARS-CoV-1 and SARS-CoV-2 viability, susceptibility to treatment, and the disinfection and reuse of PPE, particularly filtering facepiece respirators. Int J Environ Res Public Health 17: $6117 . \quad$ doi: 10.3390/ijerph17176117

Dong Y, Mo X, Hu Y, Qi X, Jiang F, Jiang Z, Tong $S$ (2020) Epidemiology of COVID19 among children in China. Pediatrics 145: e20200702. doi: 10.1542/peds.2020-0702

Duan SM, Zhao XS, Wen RF, Huang JJ, Pi GH, Zhang SX, Han J, Bi SL, Ruan L, Dong XP (2003) Stability of SARS coronavirus in human specimens and environment and its sensitivity to heating and UV irradiation. Biomed Environ Sci 16: 246-255. PMID: 14631830

Fennelly KP (2020) Particle sizes of infectious aerosols: Implications for infection control. Lancet Respir Med 8: 914-924. doi: 10.1016/S2213-2600(20)30323-4

Gorbalenya AE, Baker SC, Baric RS, de Groot RJ, Drosten C, Gulyaeva AA, Haagmans BL, Lauber C, Leontovich AM, Neuman BW, Penzar D, Perlman S, Poon LLM, Samborskiy DV, Sidorov IA, Sola I, Ziebuhr J (2020) The species severe acute respiratory syndromerelated coronavirus: Classifying 2019nCoV and naming it SARS-CoV-2. Nat Microbiol 5: 536-544. doi: 10.1038/s41564-020-0695-z

Greatorex JS, Page RF, Curran MD, Digard $P$, Enstone JE, Wreghitt T, Powell PP, Sexton DW, Vivancos R, Nguyen-VanTam JS (2010) Effectiveness of common household cleaning agents in reducing the viability of human influenza A/H1N1. PLoS One 5: e8987. doi: 10.1371/journal.pone.0008987
Heilingloh CS, Aufderhorst UW, Schipper L, Dittmer U, Witzke O, Yang D, Zheng X, Sutter K, Trilling M, Alt M, Steinmann E, Krawczyk A (2020) Susceptibility of SARS-CoV-2 to UV irradiation. Am J Infect Control 48: 1273-1275. doi: 10.1016/j.ajic.2020.07.031

Herman J, Biegel B, Huang L (2021) Inactivation times from 290 to $315 \mathrm{~nm}$ UVB in sunlight for SARS coronaviruses CoV and CoV-2 using OMI satellite data for the sunlit Earth. Air Qual Atmos Health 14:217-233. doi: 10.1007/s11869-020-00927-2.

Hermans RD, Langowski PH, Ninomura PT, Seth AK, Cohen T, Shaughnessy DE, Freeman GA, Sheerin MP, Hendrickson GL, Weber RJ, Keen MR, Woolsey ME, Kennedy SD, Jones BW, Crowther HF, Kohler JA, Baker RG, Lutz JD, Martin RM, Bushby ST, Myers F, Cooper KW, Newman HM (2008) Ventilation of health care facilities. ASHRAE/ASHE Standard 170-2008.

Herndon JM, Hoisington RD, Whiteside M (2018) Deadly ultraviolet UV-C and UV$B$ penetration to earth's surface: Human and environmental health implications. J Geogr Environ Earth Sci Int 14: 1-11. doi: 10.9734/jgeesi/2018/40245

Hu D, Zhu C, Ai L, He T, Wang Y, Ye F, Yang L, Ding C, Zhu X, Lv R, Zhu J, Hassan B, Feng Y, Tan W, Wang C (2018) Genomic characterization and infectivity of a novel SARS-like coronavirus in Chinese bats. Emerg Microbes Infect 7: 154. doi: 10.1038/s41426-018-0155-5

Ing EB, Xu QA, Salimi A, Torun N (2020) Physician deaths from corona virus (COVID-19) disease. Occup Med (Lond) 70: 370-374. doi: 10.1093/occmed/kqaa088

lyengar KP, Ish P, Upadhyaya GK, Malhotra N, Vaishya R, Jain VK (2020) COVID19 and mortality in doctors. Diabetes Metab Syndr 14: 1743-1746. doi: 10.1016/j.dsx.2020.09.003

Kahn JS, Mclntosh K (2005) History and recent advances in coronavirus discovery. Pediatr Infect Dis J 24: S223S227. doi: 10.1097/01.inf.0000188166.17324.60

Khazova M, Johnstone L, Naldzhiev D, O'Hagan JB (2021) Survey of home-use 
UV disinfection products. Photochem Photobiol 97: 560-565. doi: 10.1111/php.13423

Kim D, Lee JY, Yang JS, Kim JW, Kim VN, Chang $H$ (2020) The Architecture of SARS-CoV-2 transcriptome. Cell 181: 914-921.e10.

doi: 10.1016/j.cell.2020.04.011

Kitagawa H, Nomura T, Nazmul T, Omori K, Shigemoto N, Sakaguchi T, Ohge H (2021) Effectiveness of 222-nm ultraviolet light on disinfecting SARSCoV-2 surface contamination. Am J Infect Control 49: 299-301. doi: 10.1016/j.ajic.2020.08.022

Lednicky JA, Lauzardo M, Fan ZH, Jutla A, Tilly TB, Gangwar M, Usmani $M$, Shankar SN, Mohamed K, EigurenFernandez A, Stephenson CJ, Alam MM, Elbadry MA, Loeb JC, Subramaniam K, Waltzek TB, Cherabuddi K, Morris JG, Wu CY (2020) Viable SARS-CoV-2 in the air of a hospital room with COVID-19 patients. Int J Infect Dis 100: 476-482. doi: 10.1016/j.ijid.2020.09.025

Li Q, Guan X, Wu P, Wang X, Zhou L, Tong $Y$, Ren R, Leung KSM, Lau EHY, Wong JY, Xing X, Xiang N, Wu Y, Li C, Chen Q, Li D, Liu T, Zhao J, Man Liu M, Tu W, Chen C, Jin L, Yang R, Wang Q, Zhou $S$, Wang $R$, Liu $H$, Luo $Y$, Liu $Y$, Shao G, Li H, Tao Z, Yang Y, Deng Z, Liu B, Ma Z, Zhang Y, Shi G, Lam TTY, Wu JT, Gao GF, Cowling BJ, Yang B, Leung GM, Feng Z (2020) Early transmission dynamics in Wuhan, China, of novel coronavirus-infected pneumonia. N Engl J Med 382: 11991207. doi: 10.1056/NEJMoa2001316

Liu Y, Ning Z, Chen Y, Guo M, Liu Y, Gali NK, Sun L, Duan Y, Cai J, Westerdahl D, Liu X, Xu K, Ho KF, Kan H, Fu Q, Lan K (2020) Aerodynamic analysis of SARSCoV-2 in two Wuhan hospitals. Nature 582: 557-560. doi: 10.1038/s41586020-2271-3

Lombardi ME, Ladman BS, Alphin RL, Benson ER (2008) Inactivation of avian influenza virus using common detergents and chemicals. Avian Dis 52: 118-123. doi: 10.1637/8055070907-reg

Masotti F, Cattaneo S, Stuknytè M, De Noni I (2019) Airborne contamination in the food industry: An update on monitoring and disinfection techniques of air. Trends Food Sci Technol 90: 147-156. doi: 10.1016/j.tifs.2019.06.006

Miller-Leiden S, Lobascio C, Nazaroff WW, Macher JM (1996) Effectiveness of inroom air filtration and dilution ventilation for tuberculosis infection control. J Air Waste Manag Assoc 46: 869-882. doi: 10.1080/10473289.1996.10467523

Millet JK, Whittaker GR (2015) Host cell proteases: Critical determinants of coronavirus tropism and pathogenesis. Virus Res 202: 120-134. doi: 10.1016/j.virusres.2014.11.021

Morawska L, Tang JW, Bahnfleth W, Bluyssen PM, Boerstra A, Buonanno G, Cao J, Dancer S, Floto A, Franchimon F, Haworth C, Hogeling J, Isaxon C, Jimenez JL, Kurnitski J, Li Y, Loomans M, Marks G, Marr LC, Mazzarella L, Melikov AK, Miller S, Milton DK, Nazaroff W, Nielsen P V., Noakes C, Peccia J, Querol X, Sekhar C, Seppänen O, Tanabe SI, Tellier R, Tham KW, Wargocki P, Wierzbicka A, Yao M (2020) How can airborne transmission of COVID-19 indoors be minimised? Environ Int 142: 105832. doi: 10.1016/j.envint.2020.105832

Mphaphlele M, Dharmadhikari AS, Jensen PA, Rudnick SN, van Reenen TH, Pagano MA, Leuschner W, Sears TA, Milonova SP, van der Walt M, Stoltz AC, Weyer K, Nardell EA (2015) Institutional tuberculosis transmission. Controlled trial of upper room ultraviolet air disinfection: A basis for new dosing guidelines. Am J Respir Crit Care Med 192: 477-484. doi: 10.1164/rccm.201501-00600C

Nardell EA (2021) Air disinfection for airborne infection control with a focus on COVID19: Why germicidal UV is essential. Photochem Photobiol 97: 493-497. doi: 10.1111/php.13421

Nardell EA, Nathavitharana RR (2020) Airborne spread of SARS-CoV-2 and a potential role for air disinfection. JAMA 324: 141-142. doi: 10.1001/jama.2020.7603

Nienhaus A, Hod R (2020) COVID-19 among health workers in germany and Malaysia. Int $\mathrm{J}$ Environ Res Public Health 17: 4881. doi: 
10.3390/ijerph17134881

Nissen K, Krambrich J, Akaberi D, Hoffman T, Ling J, Lundkvist $\AA$, Svensson L, Salaneck E (2020) Long-distance airborne dispersal of SARS-CoV-2 in COVID-19 wards. Sci Rep 10: 19589. doi: 10.1038/s41598-020-76442-2

Pagat AM, Seux-Goepfert R, Lutsch C, Lecouturier V, Saluzzo JF, Kusters IC (2007) Evaluation of SARS-coronavirus decontamination procedures. Appl Biosaf 12: 100-108. doi: 10.1177/153567600701200206

Pan J, Yao Y, Liu Z, Meng X, Ji JS, Qiu Y, Wang W, Zhang L, Wang W, Kan H (2021) Warmer weather unlikely to reduce the COVID-19 transmission: An ecological study in 202 locations in 8 countries. Sci Total Environ 753: 142272. doi: 10.1016/j.scitotenv.2020.142272

Pani SK, Lin NH, RavindraBabu S (2020) Association of COVID-19 pandemic with meteorological parameters over Singapore. Sci Total Environ 740: 140112. doi: 10.1016/j.scitotenv.2020.140112

Pastorino B, Touret F, Gilles M, de Lamballerie X, Charrel RN (2020) Heat inactivation of different types of SARSCoV-2 samples: What protocols for biosafety, molecular detection and serological diagnostics? Viruses 12: 735. doi: $10.3390 / v 12070735$

Ratnesar-Shumate S, Williams G, Green B, Krause M, Holland B, Wood S, Bohannon J, Boydston J, Freeburger D, Hooper I, Beck K, Yeager J, Altamura LA, Biryukov J, Yolitz J, Schuit M, Wahl V, Hevey M, Dabisch P (2020) Simulated sunlight rapidly inactivates SARS-CoV-2 on surfaces. J Infect Dis 222: 214-222. doi: 10.1093/infdis/jiaa274

Rodriguez-Martinez CE, Sossa-Briceño MP, Cortés JA (2020) Decontamination and reuse of N95 filtering facemask respirators: A systematic review of the literature. Am J Infect Control 48: 15201532. doi: 10.1016/j.ajic.2020.07.004

Saini V, Sikri K, Batra SD, Kalra P, Gautam K (2020) Development of a highly effective low-cost vaporized hydrogen peroxide-based method for disinfection of personal protective equipment for their selective reuse during pandemics.
Gut Pathog 12: 29. doi: 10.1186/s13099-020-00367-4

Schoeman D, Fielding BC (2019) Coronavirus envelope protein: Current knowledge. Virol J 16: 69. doi: 10.1186/s12985-019-1182-0

Schuit M, Gardner S, Wood S, Bower K, Williams G, Freeburger D, Dabisch P (2020a) The influence of simulated sunlight on the inactivation of influenza virus in aerosols. J Infect Dis 221: 372378. doi: 10.1093/infdis/jiz582

Schuit M, Ratnesar-Shumate S, Yolitz J, Williams G, Weaver W, Green B, Miller D, Krause M, Beck K, Wood S, Holland B, Bohannon J, Freeburger D, Hooper I, Biryukov J, Altamura LA, Wahl V, Hevey M, Dabisch P (2020b) Airborne SARSCoV-2 is rapidly inactivated by simulated sunlight. J Infect Dis 222: 564-571. doi: 10.1093/infdis/jiaa334

Schulz-Stübner S, Kosa R, Henker J, Mattner $F$, Friedrich A (2019) Is UV-C "light wand" mobile disinfection in air ambulance helicopters effective ? Infect Control Hosp Epidemiol 40: 1323-1326. doi: 10.1017/ice.2019.225.

Secretariat, M. A. (2005). Air cleaning technologies: an evidence-based analysis. Ontario Health Technology Assessment Series, 5(17):1.

Setti L, Passarini F, De Gennaro G, Barbieri $\mathrm{P}$, Perrone MG, Borelli M, Palmisani J, Di Gilio A, Piscitelli P, Miani A (2020) Airborne transmission route of COVID19: Why 2 meters/ 6 feet of interpersonal distance could not be enough. Int J Environ Res Public Health 17: 2932. doi: 10.3390/ijerph17082932

Shereen MA, Khan S, Kazmi A, Bashir N, Siddique R (2020) COVID-19 infection: Origin, transmission, and characteristics of human coronaviruses. $J$ Adv Res 24: 91-98. doi: 10.1016/j.jare.2020.03.005

Shi M, Lin XD, Tian JH, Chen LJ, Chen X, Li CX, Qin XC, Li J, Cao JP, Eden JS, Buchmann J, Wang W, Xu J, Holmes EC, Zhang YZ (2016) Redefining the invertebrate RNA virosphere. Nature 540: 539-543. doi: 10.1038/nature20167

Simmons SE, Carrion R, Alfson KJ, Staples $H M$, Jinadatha C, Jarvis WR, Sampathkumar P, Chemaly RF, Khawaja F, Povroznik M, Jackson S, 
Kaye KS, Rodriguez RM, Stibich MA (2020) Deactivation of SARS-CoV-2 with pulsed-xenon ultraviolet light: Implications for environmental COVID19 control. Infect Control Hosp Epidemiol 42: 127-130. doi: 10.1017/ice.2020.399

Somsen GA, van Rijn C, Kooij S, Bem RA, Bonn D (2020) Small droplet aerosols in poorly ventilated spaces and SARSCoV-2 transmission. Lancet Respir Med 8: 658-659. doi: 10.1016/S22132600(20)30245-9

Steinberg BE, Aoyama K, McVey M, Levin D, Siddiqui A, Munshey F, Goldenberg NM, Faraoni D, Maynes JT (2020) Efficacy and safety of decontamination for N95 respirator reuse: A systematic literature search and narrative synthesis. Can J Anesth 67: 1814-1823. doi: 10.1007/s12630-020-01770-w

Tang S, Mao Y, Jones RM, Tan Q, Ji JS, Li N, Shen J, Lv Y, Pan L, Ding P, Wang X, Wang Y, Maclntyre CR, Shi X (2020a) Aerosol transmission of SARS-CoV-2? Evidence, prevention and control. Environ Int 144: 106039. doi: 10.1016/j.envint.2020.106039

Tang Y-W, Schmitz JE, Persing DH, Stratton CW (2020b) Laboratory diagnosis of COVID-19: Current issues and challenges. J Clin Microbiol 58: e0051220. doi: $10.1128 / J C M .00512-20$

Tosepu R, Gunawan J, Effendy DS, Ahmad OAl, Lestari H, Bahar H, Asfian P (2020) Correlation between weather and Covid19 pandemic in Jakarta, Indonesia. Sci Total Environ 725: 138436. doi: 10.1016/j.scitotenv.2020.138436

Tseng CC, Li CS (2005) Inactivation of viruscontaining aerosols by ultraviolet germicidal irradiation. Aerosol Sci Technol 39: 1136-1142. doi: $10.1080 / 02786820500428575$

Tseng CC, Li CS (2007) Inactivation of viruses on surfaces by ultraviolet germicidal irradiation. J Occup Environ Hyg 4: 400-405. doi: 10.1080/15459620701329012

Uddin M, Mustafa F, Rizvi TA, Loney T, Al Suwaidi $\mathrm{H}$, Al-Marzouqi $\mathrm{AHH}$, Eldin AK, Alsabeeha N, Adrian TE, Stefanini C, Nowotny N, Alsheikh-Ali A, Senok AC (2020) SARS-CoV-2/COVID-19: Viral genomics, epidemiology, vaccines, and therapeutic interventions. Viruses 12: 526. doi: 10.3390/v12050526

van Doremalen N, Bushmaker T, Morris DH, Holbrook MG, Gamble A, Williamson BN, Tamin A, Harcourt JL, Thornburg NJ, Gerber SI, Lloyd-Smith JO, de Wit E, Munster VJ (2020) Aerosol and surface stability of SARS-CoV-2 as compared with SARS-CoV-1. N Engl J Med 382: 1564-1567. doi: 10.1056/nejmc2004973

Walker CM, Ko G (2007) Effect of ultraviolet germicidal irradiation on viral aerosols. Environ Sci Technol 41: 5460-5465. doi: 10.1021/es070056u

Walls AC, Park YJ, Tortorici MA, Wall A, McGuire AT, Veesler D (2020) Structure, function, and antigenicity of the SARS-CoV-2 spike glycoprotein. Cell 181: 281-292.e6. doi: 10.1016/j.cell.2020.02.058

Wang $Q$, Wu J, Wang $H$, Gao $Y$, Liu Q, Mu A, Ji W, Yan L, Zhu Y, Zhu C, Fang X, Yang $X$, Huang $Y$, Gao H, Liu F, Ge J, Sun $Q$, Yang $X, X u$ W, Liu Z, Yang $H$, Lou Z, Jiang B, Guddat LW, Gong $P$, Rao Z (2020) Structural basis for RNA replication by the SARS-CoV-2 polymerase. Cell 182: 417-428.e13. doi: 10.1016/j.cell.2020.05.034

WHO (2020) Rational use of personal protective equipment (PPE) for coronavirus disease (COVID-19). Interim guidance 19 March 2020. World Health Organization. https://apps.who.int/iris/bitstream/handl e/10665/331498/WHO-2019-nCoVIPCPPE_use-2020.2-eng.pdf

WHO (2021) WHO coronavirus (COVID-19) dashboard, World Health Organization. https://covid19.who.int/

Wu F, Zhao S, Yu B, Chen YM, Wang W, Song ZG, Hu Y, Tao ZW, Tian JH, Pei YY, Yuan ML, Zhang YL, Dai FH, Liu Y, Wang QM, Zheng JJ, Xu L, Holmes EC, Zhang YZ (2020a) A new coronavirus associated with human respiratory disease in China. Nature 579: 265-269. doi: 10.1038/s41586-020-2008-3

Wu Y, Jing W, Liu J, Ma Q, Yuan J, Wang Y, Du M, Liu M (2020b) Effects of temperature and humidity on the daily new cases and new deaths of COVID19 in 166 countries. Sci Total Environ 729: 139051 . doi: 
10.1016/j.scitotenv.2020.139051

Xu B, Gutierrez B, Mekaru S, Sewalk K, Goodwin L, Loskill A, Cohn EL, Hswen Y, Hill SC, Cobo MM, Zarebski AE, Li S, Wu CH, Hulland E, Morgan JD, Wang L, O'Brien K, Scarpino SV, Brownstein JS, Pybus OG, Pigott DM, Kraemer MUG (2020a) Epidemiological data from the COVID-19 outbreak, real-time case information. Sci Data 7: 106. doi: 10.1038/s41597-020-0448-0

Xu XW, Wu XX, Jiang XG, Xu KJ, Ying LJ, Ma CL, Li SB, Wang HY, Zhang S, Gao HN, Sheng JF, Cai HL, Qiu YQ, Li LJ (2020b) Clinical findings in a group of patients infected with the 2019 novel coronavirus (SARS-Cov-2) outside of Wuhan, China: Retrospective case series. BMJ 368: m606. doi: 10.1136/bmj.m606 